\title{
Factors Affecting the Induction of Phenotypically Determined Serum Resistance of Neisseria gonorrhoeae Grown in Media Containing Serum or its Diffusible Components
}

\author{
By D. R. VEALE, C. W. PENN AND H. SMITH* \\ Department of Microbiology, University of Birmingham, P.O. Box 363 , \\ Birmingham B15 2TT
}

(Received 23 May 1980)

\begin{abstract}
Phenotypically determined resistance of gonococci to killing by normal human serum can be generated by growth of susceptible organisms in media containing guinea pig, calf or human serum. However, even in the best medium tested, i.e. defined medium containing $50 \%(\mathrm{v} / \mathrm{v})$ guinea pig serum, resistance was greatly reduced after $24 \mathrm{~h}$ incubation and the maximum number of colony-forming units generated was $10^{7}$ to $10^{8} \mathrm{ml}^{-1}$. Resistance was not acquired after incubation in guinea pig serum at low temperature $\left(8^{\circ} \mathrm{C}\right)$, supporting previous indications that metabolic activity was necessary for the generation of resistance. Alteration of the concentration of glutamine, proline, lactate or iron had little or no effect on the generation of serum resistance under the conditions used. Optimum conversion to resistance occurred at $\mathrm{pH} 6.0$ to 6.5 and both non-diffusible and diffusate fractions of dialysed guinea pig serum promoted resistance. Furthermore, resistant organisms could be produced by incubation in defined medium containing the diffusate from guinea pig serum and $0.1 \%$ bovine serum albumin, a step which should facilitate identification of the resistance-promoting factor.
\end{abstract}

\section{IN TRODUCTION}

The ability of gonococci to resist killing by normal human serum has long been recognized as being of potential importance in pathogenesis (Spink \& Keefer, 1937; Ward et al., 1970). Some gonococcal strains isolated from urethral pus (Ward et al., 1970), guinea pig chambers (Penn et al., 1977a, b) and, in particular, from cases of disseminated gonorrhoea (Schoolnik et al., 1976) exhibited a stable resistance to killing by normal human serum which was apparently unaffected by cultural conditions. Other isolates from urethral pus and guinea pig chambers rapidly lost their resistance to serum killing on subculture (Ward et al., 1970; Penn et al., 1977a; Rittenberg et al., 1977), as did strains which had been rendered resistant by culture in human serum (McCutchan et al., 1976). The present study is concerned with this unstable type of resistance.

The resistance to killing by normal human serum of gonococci grown in subcutaneous guinea pig chambers (strain BS4) was lost after two or three generations in broth in vitro (Rittenberg et al., 1977). Conversely, a serum-sensitive strain [BS4 (agar); produced by culturing chamber-grown organisms once on agar] rapidly gained resistance when grown in chamber fluid in vivo (Rittenberg et al., 1977). The resistance of BS4 (agar) organisms was examined after incubation in chamber fluid in vitro at $37^{\circ} \mathrm{C}$ for 0 to $24 \mathrm{~h}$. The organisms remained sensitive for about $30 \mathrm{~min}$ then became resistant by $1 \mathrm{~h}$ and remained so for about ten generations until they reverted to susceptibility at 12 to $24 \mathrm{~h}$ (Goldner et al., 1979). Hence, the gain and loss of resistance was probably phenotypically determined and was not the result of mutation and selection. The inability of sensitive organisms to gain resistance in 
chamber fluid in vitro during $30 \mathrm{~min}$ at $37^{\circ} \mathrm{C}$ or when incubated at $25^{\circ} \mathrm{C}$ or $4^{\circ} \mathrm{C}$ suggested that the resistance was dependent on metabolic activity and was not due to non-specific adsorption of media components by the organisms. Preliminary investigation of the conditions promoting resistance to serum killing indicated that neither redox potential nor glucose concentration were involved; in contrast, lactate, glutamate and proline were possibly important as chamber fluid became depleted in these components during growth of gonococci in vitro (Goldner et al., 1979).

This paper describes further steps towards the identification of the resistance-promoting factor. Resistance has been generated using mixtures of a defined medium and serum (chiefly guinea pig) or serum diffusate instead of chamber fluid. The conditions under which phenotypically determined resistance is produced have been investigated. Special attention was given to the roles of $\mathrm{pH}$ and iron in view of their effect on gonococcal surface properties (Hebeler \& Morse, 1976; Magnusson et al., 1979a, b) and to the roles of proline, glutamine and lactate. Also, the possibility that gonococci were transformed rapidly to serum resistance by extracellular DNA was investigated.

\section{METHODS}

Organisms. Neisseria gonorrhoeae strains BS4 (agar) and BSSH were derived and cultured as described previously (Penn et al., 1976, 1977 a; Goldner et al., 1979). Organisms were stored at $-70^{\circ} \mathrm{C}$ or in liquid nitrogen and were used directly after thawing or after a single subculture on agar.

Media, cultural and counting procedures. These were as described previously (Veale et al., 1975; Penn et al., 1976, 1977a).

Guinea pig chamber fluid and various sera. Chamber fluid was collected from five to ten chambers which had been in situ on guinea pigs for at least 6 weeks (Veale et al., 1975), centrifuged ( $1000 \mathrm{~g}$ for 5 to $10 \mathrm{~min}$ ), filtered through a Millipore membrane (pore size $0.22 \mu \mathrm{m}$ ) and stored at $-20^{\circ} \mathrm{C}$ without heat inactivation. Pooled guinea pig serum was collected by cardiac puncture under ether-induced anaesthesia. Calf (Oxoid), newborn calf (Flow Laboratories; Wellcome; Gibco Biocult, Paisley; Tissue Culture Services, Slough), swine (Flow Laboratories), sheep and horse (Tissue Culture Services) sera were obtained from the commercial sources indicated. Human serum was obtained from healthy donors and was not pooled. Unless otherwise stated all sera were heat-inactivated at $56^{\circ} \mathrm{C}$ for 30 to $60 \mathrm{~min}$ and stored at $-20^{\circ} \mathrm{C}$. L ( + -Lactate concentrations in guinea pig and swine sera were measured using a lactate dehydrogenase- $\mathrm{NAD}^{+}$assay (Boehringer) and free proline and glutamine concentrations were measured by ion exchange chromatography and ninhydrin spectrophotometry by the Macromolecular Analysis Service (Birmingham University).

Dialysis of guinea pig and swine sera. Samples of these sera (1 to $20 \mathrm{ml})$ were dialysed for 16 to $18 \mathrm{~h}$ at $4{ }^{\circ} \mathrm{C}$ in $8 / 32$ inch Visking tubing (Medicell International, London) against 25 to 30 vol. distilled and deionized water to extract low molecular weight ( $<12000$ to 14000) components (diffusate) and then against two to three changes of distilled water ( $2 \mathrm{l}$ ) over a 24 to $48 \mathrm{~h}$ period to extract residual low molecular weight material. Both diffusate and non-diffusible material (retentate; molecular weight $>12000$ to 14000) were freeze dried, resuspended in distilled water so that components were approximately twofold concentrated with respect to the original serum, and stored at $-20^{\circ} \mathrm{C}$.

Defined medium. Liquid medium was prepared as described by Morse \& Bartenstein (1980) but without the addition of uracil. Phenol red $\left(10 \mathrm{mg}^{-1}\right)$ was added to the medium and the $\mathrm{pH}$ was adjusted to 7.0 to 7.2 unless otherwise stated. Strain BS4 (agar) did not grow in this medium at low inoculum $\mathrm{l}<10^{7}$ colony-forming units (c.f.u.) $\mathrm{ml}^{-1}$ ] without the addition of serum or bovine serum albumin (Sigma). In some experiments, $0.2 \%(\mathrm{w} / \mathrm{v})$ $\mathrm{Fe}\left(\mathrm{NO}_{3}\right)_{3} \cdot 9 \mathrm{H}_{2} \mathrm{O}$ (Hopkin \& Williams) was added to the defined medium and the $\mathrm{pH}$ was adjusted to 7 with $\mathrm{NaOH}$. This resulted in the formation of a flocculent white precipitate (probably mainly ferric phosphate) so the actual concentration of $\mathrm{Fe}^{3+}$ in the medium was unknown. Other modifications made to the medium were the substitution of glucose by $0.5 \%(\mathrm{w} / \mathrm{v}) \mathrm{L}(+)$-lactic acid and the addition of proline (Sigma), glutamine (Sigma) and DNAase (2425 Kunitz units $\mathrm{mg}^{-1}$; Sigma) at the concentrations stated in the text. In other experiments, proline, glutamine or iron were omitted from the defined medium.

Generation of resistant organisms (conditioning). Media usually consisted of a 1:1 mixture of serum and defined medium, as growth in this mixture was more consistent than in serum or chamber fluid alone. Swine serum, which did not generate resistant organisms, was used as a negative control and sometimes as a diluent for other sera. In experiments with dialysed serum components, the medium consisted of defined medium containing either $25 \%(\mathrm{v} / \mathrm{v})$ retentate (twofold concentrate) or $25 \%(\mathrm{v} / \mathrm{v})$ bovine serum albumin solution $(0.4 \%, \mathrm{w} / \mathrm{v}$, in distilled water) and either $25 \%(\mathrm{v} / \mathrm{v})$ diffusate (twofold concentrate; homologous or heterologous) or $25 \%(\mathrm{v} / \mathrm{v})$ phosphate 
buffered saline (PBS; pH 7.2, at twice physiological concentration). One vol. of gonococcal suspension diluted (unless otherwise stated) to about $10^{6} \mathrm{c}$.f.u. $\mathrm{ml}^{-1}$ in defined medium was added to 10 vol. of the medium under test (total vol. usually $110 \mu \mathrm{l}$ ) and incubated in the wells of sealed polystyrene microtitration plates (Flow Laboratories) or sealed polypropylene $2 \mathrm{ml}$ ampoules. The length and temperature of incubation was varied as described in the text and tables but, in most experiments, organisms were conditioned for $3 \mathrm{~h}$ at $37^{\circ} \mathrm{C}$.

Measurement of resistance to killing by normal human serum. A modification of the test of Goldner et al. (1979) was used. Fresh human serum was collected from a pool of seven to ten donors. Half the serum was heated at $56^{\circ} \mathrm{C}$ for $60 \mathrm{~min}$ and then stored in $0.5 \mathrm{ml}$ portions at $-20^{\circ} \mathrm{C}$ : the remainder (unheated) was stored in $0.5 \mathrm{ml}$ portions at $-70^{\circ} \mathrm{C}$. Both the unheated and heated sera were thawed at room temperature immediately before use. Ten $\mu \mathrm{l}$ of unheated or heated (control) serum, $30 \mu \mathrm{l}$ defined medium and $4 \mu \mathrm{l}$ of the test organisms (about $10^{5}$ c.f.u. $\mathrm{ml}^{-1}$ ) in defined medium were added to the wells of polystyrene microtitration trays. The trays were sealed, agitated gently to mix the contents and incubated at $37^{\circ} \mathrm{C}$ for $40 \mathrm{~min}$. Then $60 \mu \mathrm{l}$ defined medium was added to each well before plating $100 \mu$ lo determine the viable count. Each treatment was carried out in duplicate. In some of the earlier experiments, a larger incubation volume of $110 \mu \mathrm{l}$ was used (cf. Goldner et al., 1979) but the proportions of serum, defined medium and gonococcal suspension were the same as above; the results of these tests were similar to those with the smaller incubation volume. The count of viable gonococci usually increased during the $40 \mathrm{~min}$ control incubation in heated serum [mean increase 95\%, standard error (s.E.) $32 \% ; 19$ determinations]. Resistance to killing by human serum was calculated as the number of c.f.u. recovered after incubation with unheated serum expressed as a percentage of the number recovered after incubation with heated serum. Resistances numerically greater than $100 \%$ were taken as $100 \%$ for calculating averages. As a further control on the bactericidal activity of unheated human serum, serum killing tests were also performed on serum-sensitive organisms before addition to the resistance-generating medium. The effect of carry-over of $\mathrm{Fe}^{3+}$ or guinea pig serum from incubation media into the serum killing test and of lowering the $\mathrm{pH}$ were assessed by adding $0 \cdot 1 \%(\mathrm{w} / \mathrm{v}) \mathrm{Fe}\left(\mathrm{NO}_{3}\right)_{3} \cdot 9 \mathrm{H}_{2} \mathrm{O}$ or $5 \%(\mathrm{v} / \mathrm{v})$ guinea pig serum to the test, or reduction of the $\mathrm{pH}$ to $6 \cdot 5$. These treatments did not significantly affect the killing of serum-sensitive organisms by unheated human serum.

Estimate of survival and growth during the conditioning periods. Direct measurement of growth was not attempted owing to the difficulty of measuring the number of viable organisms in the inoculum: organisms taken immediately from cold storage are susceptible to loss of viability on solid medium (Rittenberg et al., 1977). However, an estimate of the net amount of survival or growth during the conditioning period was obtained by incubating samples, taken before and after conditioning, with heated human serum for 40 min at $37^{\circ} \mathrm{C}$ (as in the test described above) before plating to determine the viable count. The count made after the conditioning period was expressed as a percentage of the initial count.

\section{RES ULTS}

Conversion of serum-sensitive gonococci to resistance by incubation in defined medium containing either guinea pig chamber fluid or various sera

Gonococci [strain BS4 (agar)] became resistant to killing by human serum after incubation for $3 \mathrm{~h}$ at $37^{\circ} \mathrm{C}$ in defined medium containing $50 \%(\mathrm{v} / \mathrm{v})$ of either guinea pig chamber fluid or serum from one of several species (Table 1). A high degree of resistance (often $>90 \%$ ) could be generated using guinea pig chamber fluid or guinea pig serum. Several batches of calf serum (normal, newborn or foetal) promoted resistance but this was usually partial and inconsistent. Similarly, only one sample of human serum (MH) generated consistently good resistance; the others produced poor, partial and variable resistance. As with swine serum, little or no resistance developed in media containing either sheep or horse serum ( 3 to 6 experiments each; results not shown). Attempts to use a medium similar to those used by Swanson (1977) and Ward et al. (1978) for growing capsulated gonococci failed because strain BS4 (agar) survived poorly in this medium. Reduction of the concentration of guinea pig serum to $5 \%$ by dilution in swine serum decreased the proportion of resistant organisms generated.

There was variation in the estimates of growth and survival during the $3 \mathrm{~h}$ conditioning period (Table 1). In most media tested the count at $3 \mathrm{~h}$ was, on average, about twice the initial count, the main exception being the poor survival in medium containing $50 \%$ swine serum. Although, in this case, poor survival was coupled with an inability to generate resistance, the correlation did not hold true for other media such as those containing $50 \%$ calf or human (other than $\mathrm{MH}$ ) serum where there was evidence of good growth but a low conversion to 


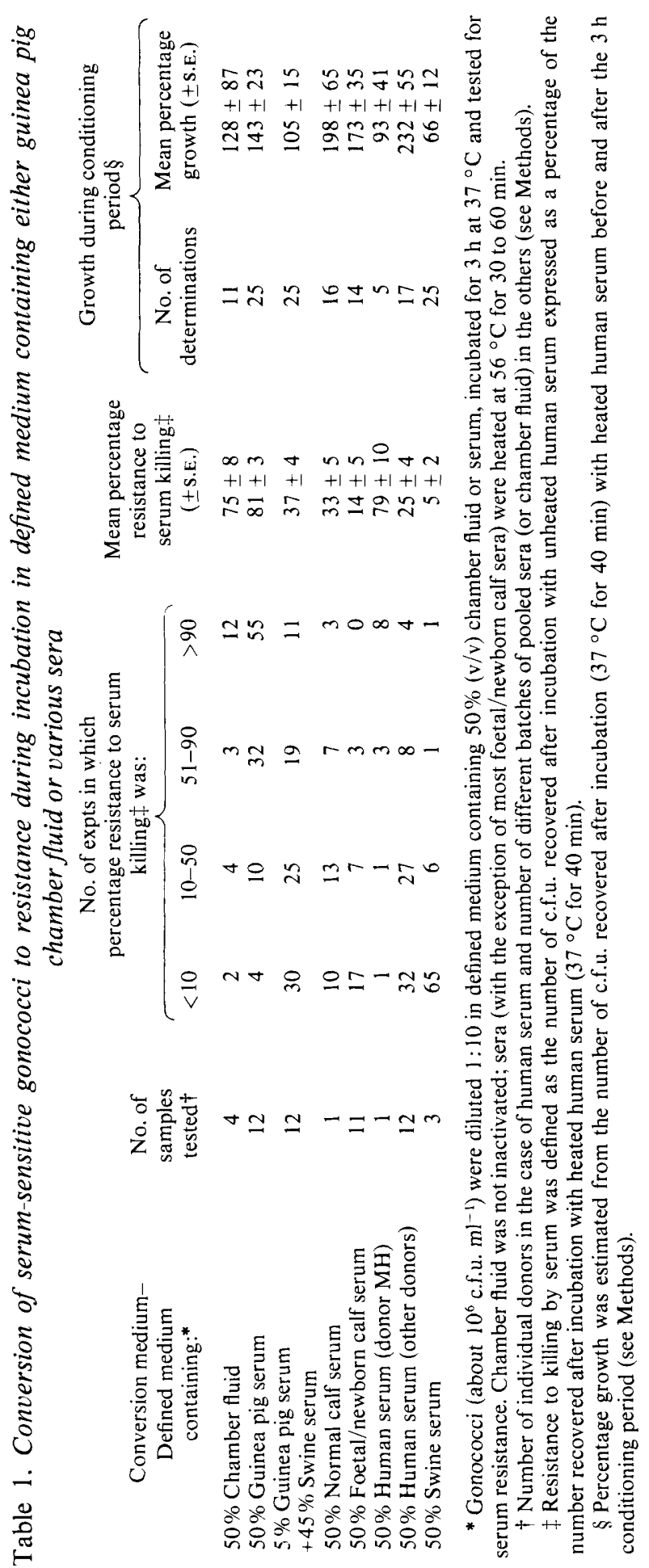


resistance. Furthermore, within individual treatment groups, there was no obvious correlation between growth during conditioning and conversion to resistance.

After prolonged $(24 \mathrm{~h})$ incubation in defined medium containing $50 \%$ guinea pig serum the viable count of gonococci was about 1000 -fold higher than at $3 \mathrm{~h}$. However, prolonged incubation resulted in loss of resistance to serum killing: in 12 experiments the mean resistance of gonococci at $24 \mathrm{~h}$ was $13 \%$ (s.E. $\pm 8 \%$ ) compared with $84 \%$ (s.E. $\pm 6 \%$ ) after $3 \mathrm{~h}$.

In 12 experiments, the initial concentration of gonococci in defined medium containing $50 \%$ guinea pig serum was raised to between $10^{7}$ and $10^{9} \mathrm{c}$.f.u. $\mathrm{ml}^{-1}$, but the maximum number of organisms with a resistance to serum killing of $>90 \%$ that could be generated in $3 \mathrm{~h}$ was only $10^{7}$ to $10^{8}$ c.f.u. $\mathrm{ml}^{-1}$. Resistance was usually partial at gonococcal concentrations $\geqslant 10^{8}$ c.f.u. $\mathrm{ml}^{-1}$.

A serum-sensitive gonococcal strain (BSSH), which had not been passaged through guinea pig chambers like strain BS4 (agar), could also be converted to resistance (mean $83 \%$, S.E. \pm $15 \%$ ) by incubation at $37^{\circ} \mathrm{C}$ for $3 \mathrm{~h}$ in either guinea pig chamber fluid alone or defined medium containing $50 \%$ guinea pig serum ( 3 experiments each).

\section{Effect of temperature of incubation and DNAase on the conversion of serum-sensitive gonococci to resistance}

Conversion of strain BS4 (agar) to serum resistance after incubation for $3 \mathrm{~h}$ in defined medium containing $50 \%$ guinea pig chamber fluid occurred at $37^{\circ} \mathrm{C}$ (mean resistance $81 \%$, S.E. $\pm 10 \%$ ) but not at $25{ }^{\circ} \mathrm{C}$ (mean resistance $3 \%$, s.E. $\pm 1 \%$ ) or $8{ }^{\circ} \mathrm{C}$ (mean resistance $4 \%$, S.E. $\pm 2 \%$ ). Conversion in defined medium containing $50 \%$ guinea pig serum was high at both $37^{\circ} \mathrm{C}$ (mean resistance $78 \%$, s.E. $\pm 8 \%$ ) and $25{ }^{\circ} \mathrm{C}$ (mean resistance $82 \%$, s.E. \pm $10 \%$ ) but was low at $8{ }^{\circ} \mathrm{C}$ (mean resistance $7 \%$, s.E. $\pm 3 \%$ ). The results after incubation in defined medium containing $5 \%$ guinea pig serum and $45 \%$ swine serum resembled those for defined medium containing $50 \%$ guinea pig chamber fluid (mean resistance at 37,25 and $8{ }^{\circ} \mathrm{C}$, respectively, 45,10 and $6 \%$, S.E. $\pm 10,10$ and $6 \%$ ). In these experiments, 5 to 15 determinations of resistance were made for each treatment.

Incubation at reduced temperatures resulted in a loss of viability during the $3 \mathrm{~h}$ conditioning period in all treatment groups. The estimated percentage survival values after incubation at $25^{\circ} \mathrm{C}$ or $8{ }^{\circ} \mathrm{C}$ were, on average, 8 -fold and 34 -fold lower, respectively, than those at $37^{\circ} \mathrm{C}$. In some experiments, an inoculum of about $10^{7}$ c.f.u. $\mathrm{ml}^{-1}$ was used for incubations at $8{ }^{\circ} \mathrm{C}$ to compensate for the loss in viability.

In 4 experiments, DNAase $\left(50 \mu \mathrm{g} \mathrm{m}^{-1}\right)$ was added to defined medium containing $50 \%$ guinea pig serum to determine whether organisms could be transformed to resistance by extracellular DNA. The conversion of gonococci to resistance after incubation for $3 \mathrm{~h}$ at $37^{\circ} \mathrm{C}$ was similar (mean resistance $89 \%$, s.E. $\pm 4 \%$ ) to that in control incubations without DNAase (mean resistance $92 \%$, S.E. $\pm 5 \%$ ).

\section{Effect of proline, glutamine, lactate and iron on the conversion of serum-sensitive gonococci to resistance}

Neither the addition of 0.01 or $0.1 \%(\mathrm{w} / \mathrm{v})$ proline to defined medium containing $5 \%$ guinea pig serum and $45 \%$ swine serum (this medium contained $(\mathrm{w} / \mathrm{v})$ about $0.004 \%$ proline, $0.005 \%$ glutamine and $0.04 \%$ lactate] nor the substitution of $0.5 \%(\mathrm{w} / \mathrm{v})$ lactate for glucose in the defined medium component had any appreciable effect on the ability of this medium to convert serum-sensitive BS4 (agar) organisms to serum resistance. The addition of 0.01 or $0.1 \%(\mathrm{w} / \mathrm{v})$ glutamine enhanced resistance in some experiments but not in others and the overall mean resistance $(38 \%$, S.E. $\pm 8 \%)$ was similar to that of the controls $(29 \%$, S.E. \pm $8 \%$ ). Each medium (modified or unmodified) was the subject of 15 to 16 determinations. In a separate series of experiments, the addition of $\mathrm{Fe}\left(\mathrm{NO}_{3}\right)_{3}$ (see Methods) to defined medium 


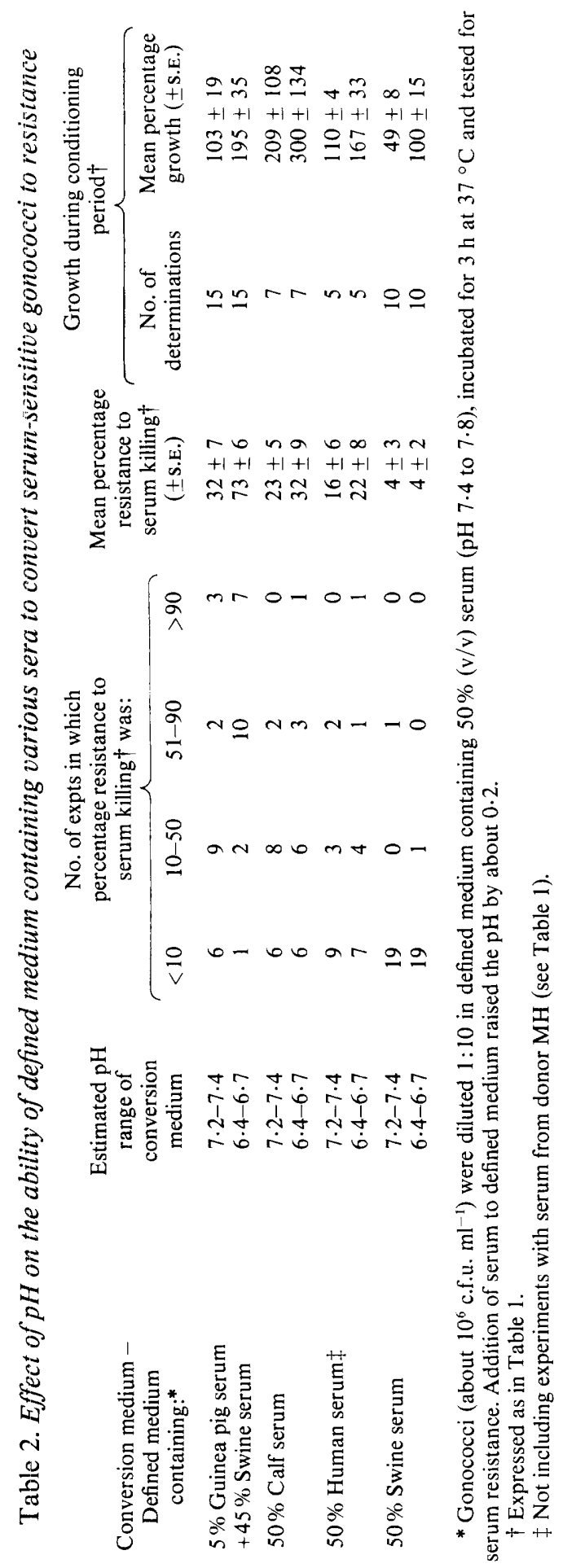


containing guinea pig serum and $45 \%$ swine serum enhanced resistance in $10 / 18$ experiments but, again, the results were variable so that the mean increase in resistance was not significant $(44 \%$, S.E. $\pm 10 \%)$ compared with medium without added iron $(27 \%$, S.E. $\pm 8 \%)$. In 6 other experiments, the effect of depletion of media with respect to proline, glutamine and iron was assessed by incubating serum-sensitive organisms in a mixture of $25 \%$ guinea pig serum retentate (which should have contained no low molecular weight components; twofold concentrate), $25 \%$ PBS and modified defined medium. These treatments had little effect on the generation of resistance.

\section{Effect of $\mathrm{pH}$ on the conversion of serum-sensitive gonococci to resistance in serum-containing media}

The effect of lowering the $\mathrm{pH}$ (to between 6.4 and 6.7 ) of various media on the generation of serum resistance in strain BS4 (agar) is shown in Table 2. After $3 \mathrm{~h}$ incubation, consistent enhancement of serum resistance was produced in defined medium containing $5 \%$ guinea pig serum and $45 \%$ swine serum. Enhancement was more variable with calf and human serum and there was no enhancement with swine serum. The optimum $\mathrm{pH}$ range for conversion in defined medium containing $5 \%$ guinea pig serum and $45 \%$ swine serum was $6 \cdot 0$ to $6 \cdot 5$.

The estimates of net growth during the $3 \mathrm{~h}$ conditioning period (Table 2) indicated that better growth occurred at the lower $\mathrm{pH}$ range. However, ony in the case of defined medium containing $5 \%$ guinea pig serum and $45 \%$ swine serum was an increased growth rate at the lower $\mathrm{pH}$ coupled with a significant increase in the conversion of sensitive organisms to resistance. As before, there was no obvious correlation within individual treatment groups between growth during conditioning and conversion to serum resistance.

Serum resistance could not be maintained for a period of $24 \mathrm{~h}$ incubation in defined medium containing $50 \%$ guinea pig serum at the lower $\mathrm{pH}$ : in 11 experiments the mean resistance after $24 \mathrm{~h}$ was $12 \%$ (S.E. $\pm 6 \%$ ) compared with $88 \%$ (S.E. $\pm 6 \%$ ) at 3 h, i.e. similar to the results obtained previously at the higher $\mathrm{pH}$. In 3 experiments, the conversion of gonococci to resistance in defined medium containing $50 \%$ guinea pig serum at the lower $\mathrm{pH}$ was considerably reduced by incubation at $8{ }^{\circ} \mathrm{C}$ (mean resistance $2 \%$, s.D. $\pm 1 \%$ ) compared with incubation at $37^{\circ} \mathrm{C}$ (mean resistance $83 \%$, s.D. $\pm 13 \%$ ). When the concentration of gonococci in the medium at the lower $\mathrm{pH}$ was raised to between $10^{7}$ and $10^{9}$ c.f.u. $\mathrm{ml}^{-1}(4$ experiments) the maximum number with a resistance to serum killing of $>90 \%$ that could be generated was similar $\left(10^{7}\right.$ to $10^{8}$ c.f.u. $\left.\mathrm{ml}^{-1}\right)$ to the number generated during the corresponding incubation at the higher $\mathrm{pH}$.

\section{Effect of heating and of dialysis on the ability of guinea pig serum to convert serum-sensitive gonococci to resistance}

Heating guinea pig serum at $56^{\circ} \mathrm{C}$ for $1 \mathrm{~h}$ had no consistent effect on its capacity to convert gonococci to serum resistance. In 16 direct comparisons of heated with unheated serum $(50 \%$ in defined medium), the mean resistances generated were $68 \%$ (s.E. $\pm 8 \%$ ) and $85 \%$ (s.E. $\pm 6 \%$ ), respectively. These figures should be compared with those in Table 1 where incubation in defined medium containing $50 \%$ heated guinea pig serum produced a mean resistance of $81 \%$ (s.E. $\pm 3 \% ; 101$ determinations).

The effect of dialysis is shown in Table 3 . The high molecular weight fraction of guinea pig serum (retentate) converted gonococci to serum resistance either alone or in combination with the diffusate from swine serum, although the resistance was not as complete as when diffusate from guinea pig serum was used. The low molecular weight fraction of guinea pig serum (diffusate) transformed organisms to high levels of resistance in combination with the retentate from swine serum (which was inactive alone or in combination with its diffusate). 
Table 3. Effect of dialysis on the ability of guinea pig and swine sera to convert serumsensitive gonococci to resistance

\begin{tabular}{|c|c|c|c|c|c|c|}
\hline \multicolumn{2}{|c|}{$\begin{array}{c}\text { Conversion medium - } \\
\text { Defined medium containing:* }\end{array}$} & \multicolumn{4}{|c|}{$\begin{array}{l}\text { No. of expts in which percentage } \\
\text { resistance to serum killing } \dagger \text { was: }\end{array}$} & \multirow{2}{*}{$\begin{array}{l}\text { Mean percentage } \\
\text { resistance to } \\
\text { serum killing } \dagger \\
( \pm \text { S.E. })\end{array}$} \\
\hline $\begin{array}{l}\text { Retentate } \\
(25 \%)\end{array}$ & $\begin{array}{c}\text { Diffusate } \\
\text { or PBS }(25 \%)\end{array}$ & $<10$ & $10-50$ & $51-90$ & $>90$ & \\
\hline Guinea pig & PBS & 4 & 1 & 6 & 1 & $46 \pm 11$ \\
\hline Guinea pig & Gruinea pig & 0 & 0 & 1 & 7 & $98 \pm 2$ \\
\hline Guinea pig & Swine & 2 & 1 & 4 & 1 & $45 \pm 13$ \\
\hline Swine & PBS & 5 & 1 & 0 & 0 & $6 \pm 6$ \\
\hline Swine & Guinea pig & 1 & 0 & 2 & 9 & $85 \pm 9$ \\
\hline Swine & Swine & 8 & 1 & 0 & 0 & $4 \pm 3$ \\
\hline
\end{tabular}

* Gonococci (about $10^{6}$ c.f.u. $\mathrm{ml}^{-1}$ ) were diluted $1: 10$ in defined medium containing $25 \%(\mathrm{v} / \mathrm{v})$ retentate (twofold concentrate) and either $25 \%(\mathrm{v} / \mathrm{v})$ diffusate (twofold concentrate) or PBS (pH $7 \cdot 2$, at twice physiological concentration), incubated for $3 \mathrm{~h}$ at $37^{\circ} \mathrm{C}$ and tested for serum resistance. Fractions from three preparations of dialysed guinea pig serum and one preparation of dialysed swine serum were used.

$\dagger$ Expressed as in Table 1 .

The estimated mean percentage growth during the $3 \mathrm{~h}$ conditioning period (expressed as in Table 1) in media containing guinea pig serum retentate was $336 \%$ (s.E. $\pm 166 \% ; 13$ determinations) and in media containing swine serum retentate was $260 \%$ (s.E. $\pm 59 \% ; 12$ determinations).

Table 4. Effect of time, temperature and $\mathrm{pH}$ of incubation on the conversion of serumsensitive gonococci to resistance during incubation in defined medium containing guinea pig serum diffusate and $0 \cdot 1 \%(w / v)$ bovine serum albumin

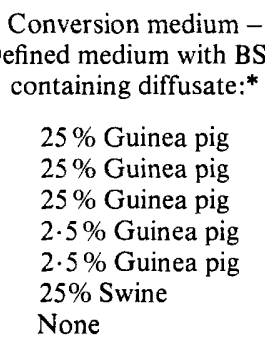

$\begin{array}{cr}\begin{array}{c}\text { Estimated pH } \\ \text { range of } \\ \text { conversion medium }\end{array} & \begin{array}{r}\text { Temp } \\ \text { of incub } \\ \left({ }^{\circ} \mathrm{C}\right)\end{array} \\ 7 \cdot 3-7 \cdot 5 & 37 \\ 7 \cdot 3-7 \cdot 5 & 8 \\ 7 \cdot 3-7 \cdot 5 & 37 \\ 7 \cdot 3-7 \cdot 5 & 37 \\ 6 \cdot 5-6 \cdot 8 & 37 \\ 7 \cdot 3-7 \cdot 5 & 37 \\ 7 \cdot 3-7 \cdot 5 & 37\end{array}$

Length of
incubation
(h)
3
3
24
3
3
3
3

* Gonococci (about $10^{6}$ c.f.u. $\mathrm{ml}^{-1}$ ) were diluted $1: 10$ in defined medium containing 2.5 or $25 \%(\mathrm{v} / \mathrm{v})$ diffusate (twofold concentrate) and $25 \%(\mathrm{v} / \mathrm{v})$ bovine serum albumin solution (BSA; $0.4 \%$, w/v), incubated under the conditions indicated and tested for serum resistance. Addition of $25 \%(\mathrm{v} / \mathrm{v})$ diffusate and BSA to the defined medium raised the $\mathrm{pH}$ by about $0 \cdot 3$. Two preparations of guinea pig serum diffusate and one of swine serum diffusate were used.

+ Expressed as in Table 1 .

† The estimated mean percentage growth during the $3 \mathrm{~h}$ conditioning period (expressed as in Table 1) was $146 \%$ (s.E. $\pm 75 \% ; 9$ determinations).

$\S$ The estimated mean percentage growth during the $3 \mathrm{~h}$ conditioning period (expressed as in Table 1) was $86 \%$ (s.E. $\pm 29 \% ; 9$ determinations).

\section{Production of serum-resistant organisms by incubation in defined medium containing diffusate from guinea pig or swine serum and bovine serum albumin}

Table 4 records the results of experiments in which the serum retentate fraction was replaced by $0.1 \%(\mathrm{w} / \mathrm{v})$ bovine serum albumin in the mixture of the diffusate from guinea pig serum and defined medium used to generate resistant organisms from strain BS4 (agar). It was not possible to test organisms incubated in a mixture of the diffusate and defined medium alone as this medium did not support the viability of strain BS4 (agar). With bovine serum albumin, guinea pig serum diffusate behaved in a similar manner to whole serum: good resistance was generated using either $25 \%$ diffusate (twofold concentrate, equivalent to that 
in $50 \%$ serum) at a slightly alkaline $\mathrm{pH}$ or $2 \cdot 5 \%$ diffusate at the lower $\mathrm{pH}$ of $6 \cdot 5$ to $6 \cdot 8$. More variable resistance was generated with $2.5 \%$ diffusate at the slightly alkaline pH. Little or no resistance was generated by incubation for $3 \mathrm{~h}$ at $8^{\circ} \mathrm{C}$ or $24 \mathrm{~h}$ at $37^{\circ} \mathrm{C}$ with guinea pig serum diffusate or for $3 \mathrm{~h}$ at $37^{\circ} \mathrm{C}$ with swine serum diffusate. When the initial concentration of gonococci in the medium, i.e. defined medium containing $25 \%$ guinea pig serum diffusate and $25 \%$ bovine serum albumin solution $(0.4 \%)$, was raised to between $10^{6}$ and $10^{9}$ c.f.u. $\mathrm{ml}^{-1}$, the maximum number of c.f.u. with a resistance to serum killing of $>90 \%$ that could be generated was $10^{6}$ to $10^{7} \mathrm{ml}^{-1}$.

\section{DIS CUS SION}

Phenotypically determined resistance of gonococci to killing by human serum could be generated by growth in media other than the guinea pig chamber fluid used in previous work (Goldner et al., 1979). Resistance could also be generated with a serum-sensitive strain (BSSH) which, unlike strain BS4 (agar), had not been passaged through guinea pig chambers.

Good resistance was obtained in guinea pig serum and poorer, more variable resistance in calf and human serum. Little or no resistance was developed with other sera (swine, sheep and horse). The result with human serum indicates that, in some cases, resistant organisms may be produced in the course of the human disease in a similar way to that in subcutaneous chambers in guinea pigs (Penn et al., 1976). The best medium for the production of resistant organisms over a $3 \mathrm{~h}$ incubation period was defined medium containing $50 \%$ guinea pig serum, but even with this medium resistance was reduced or lost by $24 \mathrm{~h}$. The maximum number of resistant c.f.u. that could be generated in $3 \mathrm{~h}$ from graded inocula was relatively low $\left(10^{7}\right.$ to $\left.10^{8} \mathrm{ml}^{-1}\right)$. This indicated, like previous experiments on the retention of resistance by organisms grown in chamber fluid in vitro (Rittenberg et al., 1977), that the resistance conferring factor was in short supply and was rapidly utilized during growth.

As in previous experiments (Goldner et al., 1979), a reduction in incubation temperature reduced the number of resistant c.f.u. generated in $3 \mathrm{~h}$ suggesting that the gain in resistance was due to an active metabolic process and not to adsorption of medium components by the organisms. There was a difference in the behaviour of the organisms in defined medium containing $50 \%$ chamber fluid, where little resistance was produced at $25{ }^{\circ} \mathrm{C}$, compared with that in defined medium containing $50 \%$ guinea pig serum where the resistance produced at 25 and $37^{\circ} \mathrm{C}$ was similar. However, incubation in defined medium containing $5 \%$ guinea pig serum and $45 \%$ swine serum produced similar results to incubation in defined medium containing $50 \%$ chamber fluid suggesting that the differences observed between guinea pig serum and chamber fluid were due to concentration effects.

Addition of DNAase, in similar quantities to those used by Norlander et al. $(1979 a, b)$ to investigate genetic exchange mechanisms in gonococci, did not affect the gain of resistance by sensitive organisms. This indicated that transformation of organisms to resistance by extracellular DNA was not involved and supported the view of Rittenberg et al. (1977) that the serum resistance was phenotypically determined.

Alteration of the concentration of proline, glutamine, lactate or iron in the medium had little effect on the generation of serum-resistant gonococci. It is therefore unlikely that any of these factors were involved to a significant extent in the generation of resistance.

Conversion to resistance in the medium containing $5 \%$ guinea pig serum had a pH optimum of 6.0 to 6.5 which is interesting since gonococci grown at $\mathrm{pH} 6.0$ have a different pattern of glucose utilization than at $\mathrm{pH} 7.2$ (Hebeler \& Morse, 1976), produce thicker cell walls (Morse \& Hebeler, 1978) and have altered surface properties (Magnusson et al., $1979 a$ ). The resistance produced at acid $\mathrm{pH}$ resembled that at slightly alkaline $\mathrm{pH}$ in that it was considerably reduced by prolonged $(24 \mathrm{~h})$ incubation and by incubation at $8{ }^{\circ} \mathrm{C}$. Alteration of the $\mathrm{pH}$ of incubation had no effect on the inability of swine serum to generate 
resistance, indicating that $\mathrm{pH}$ was a contributory factor rather than a primary factor in the production of resistance.

Growth during the $3 \mathrm{~h}$ conditioning period was variable and there did not appear to be a correlation between it and the generation of resistance to serum killing either between treatment groups or within individual treatment groups. It is therefore unlikely that differences in the ability of different media to generate resistance were related to their capacity to support gonococcal growth. A possible exception could be the incubation of organisms at low temperatures where considerable gonococcal death occurred and little resistance was generated. However, resistance was generated in defined medium containing $50 \%$ guinea pig serum at $25^{\circ} \mathrm{C}$ even though survival was poor.

The factor in the serum responsible for the gain of serum resistance appeared to be stable to heating at $56^{\circ} \mathrm{C}$. After dialysis, resistance-enhancing activity was found in the low molecular weight $(<12000$ to 14000 ) diffusate of guinea pig serum and, to a lesser extent, in the high molecular weight retentate. Resistance could be generated in medium containing diffusate from guinea pig serum and defined medium with no high molecular weight components other than bovine serum albumin $(0 \cdot 1 \%)$. The resistance generated in this medium resembled that produced in media containing serum in that it was greatly reduced by prolonged $(24 \mathrm{~h})$ or low temperature $\left(8^{\circ} \mathrm{C}\right)$ incubation and was enhanced by lowered $\mathrm{pH}$. The diffusate can now be fractionated for the active component. Once this is identified, it should allow the production in vitro of large quantities of resistant gonococci and, hence, the investigation of the surface components determining serum resistance.

We thank Mrs C. Sammons for her excellent technical assistance and the Medical Research Council for financial support.

\section{REFERENCES}

Goldner, M., Penn, C. W., Sanyal, S. C., Veale, D. R. \& SMITH, H. (1979). Phenotypically determined resistance of Neisseria gonorrhoeae to normal human serum: environmental factors in subcutaneous chambers in guinea pigs. Journal of General Microbiology 114, 169-177.

Hebeler, B. H. \& Morse, S. A. (1976). Physiology and metabolism of pathogenic Neisseria: tricarboxylic acid cycle activity in Neisseria gonorrhoeae. Journal of Bacteriology 128, 192-201.

McCutchan, J. A., Levine, S. \& Braude, A. I. (1976). Influence of colony type on susceptibility of gonococci to killing by human serum. Journal of Immunology 116, 1652-1655.

Magnusson, K.-E., Kinlström, E., Norlander, L., Norqvist, A., DAvies, J. \& Normark, S. (1979a). Effect of colony type and $\mathrm{pH}$ on surface charge and hydrophobicity of Neisseria gonorrhoeae. Infection and Immunity 26, 397-401.

Magnusson, K.-E., Kihlström, E., Norqvist, A., DAviES, J. \& NoRMARK, S. $(1979 b)$. Effect of iron on surface charge and hydrophobicity of Neisseria gonorrhoeae. Infection and Immunity 26, 402-407.

Morse, S. A. \& Bartenstein, L. (1980). Purine metabolism in Neisseria gonorrhoeae: the requirement for hypoxanthine. Canadian Journal of Microbiology 26, 13-20.

Morse, S. A. \& Hebeler, B. H. (1978). Effect of pH on growth and glucose metabolism of Neisseria gonorrhoeae. In Immunobiology of Neisseria gonorrhoeae, pp. 9-17. Edited by G. F. Brooks, E. C. Gotschlich, K. K. Holmes, W. D. Sawyer \& F. E.
Young. Washington, D.C.: American Society for Microbiology.

Norlander, L., Davies, J. \& Normark, S. (1979a). Genetic exchange mechanisms in Neisseria gonorrhoeae. Journal of Bacteriology 138, 756-761.

Norlander, L., Davies, J., Norquist, A. \& NormarK, S. $(1979 b)$ ). Genetic basis for colonial variation in Neisseria gonorrhoeae. Journal of Bacteriology 138, 762-769.

Penn, C. W., Sen, D., Veale, D. R., Parsons, N. J., SMITH, H. \& WITT, K. (1976). Morphological, biological and antigenic properties of Neisseria gonorrhoeae adapted to growth in guinea-pig subcutaneous chambers. Journal of General Microbiology 97, 35-43.

Penn, C. W., Veale, D. R., Rittenberg, S. C. \& SmITH, H. (1977a). The properties of gonococci in vivo and in vitro: selection and phenotypic change in relation to virulence. In Gonorrhoea: Epidemiology and Pathogenesis, pp. 117-131. Edited by F. A. Skinner, H. Smith \& P. D. Walker. London: Academic Press.

PenN, C. W., Veale, D. R. \& Smith, H. (1977b). Selection from gonococci grown in vitro of a colony type with some virulence properties of organisms adapted in vivo. Journal of General Microbiology 100, 147-158.

Rittenberg, S. C., Penn, C. W., Parsons, N. J., Veale, D. R. \& Smith, H. (1977). Phenotypic changes in the resistance of Neisseria gonorrhoeae to killing by normal human serum. Journal of General Microbiologv 103. 69-75. 
Schoolnik, G. K., Buchanan, T. M. \& Holmes, K. K. (1976). Gonococci causing disseminated gonococcal infection are more resistant to the bac tericidal action of normal human sera. Journal of Clinical Investigation 58, 1163-1173.

Spink, W. W. \& KeEfer, C. S. (1937). Studies on gonococcus infection II. The bacteriolytic power of whole defibrinated blood of patients with gonococcal arthritis. Journal of Clinical Investigation 16, $117-183$.

Swanson, J. (1977). Surface components associated with gonococcal-cell interactions. In The Gonococcus, pp. 369-402. Edited by R. B. Roberts. New York: John Wiley.
Veale, D. R., Smith, H., Witt, K. A. \& Marshall, R. B. (1975). Differential ability of colonial types of Neisseria gonorrhoeae to produce infection and an inflammatory response in subcutaneous perforated plastic chambers in guinea pigs and rabbits. Journal of Medical Microbiology 8, 325-335.

WARD, M. E., WATt, P. J. \& GlynN, A. A. (1970). Gonococci in urethral exudates possess a virulence factor lost on subculture. Nature, London 227 , $382-384$.

W ard, M. E., Lambden, P. R., Heckels, J. E. \& WATT, P. J. (1978). The surface properties of Neisseria gonorrhoeae: determinants of susceptibility to antibody complement killing. Journal of General Microbiology 108, 205-212. 